\title{
PENSINERGIAN MAHASISWA, DOSEN, DAN LEMBAGA DALAM PENCEGAHAN KECURANGAN AKADEMIK MAHASISWA AKUNTANSI
}

\author{
Oleh : \\ Endra Murti Sagoro \\ Staf Pengajar Jurusan P. Akuntansi Universitas Negeri Yogyakarta
}

\begin{abstract}
Abstrak
Mahasiswa merupakan generasi pengubah bangsa ke arah yang lebih baik. Mahasiswa dapat menjadi generasi pengubah bangsa jika mahasiswa memiliki kualitas akademik dan memiliki karakter yang baik. Munculnya berbagai kasus kecurangan akademik menunjukkan bahwa mahasiswa belum memiliki karakter yang baik. Kecurangan akademik muncul di berbagai jurusan di perguruan tinggi, tidak terkecuali Jurusan Akuntansi. Sebagian mahasiswa Jurusan Akuntansi adalah mahasiswa yang akan menempati posisi yang cukup strategis, yaitu di bagian keuangan baik di pemerintahan maupun swasta atau perusahaan. Jika lulusan Jurusan Akuntansi melakukan kecurangan akademik, maka ketika mereka bekerja tentunya dapat merugikan tempat mereka bekerja. Banyaknya kecurangan yang terjadi perlu segera diatasi atau dicegah. Pencegahan kecurangan akademik dapat berhasil jika mahasiswa beserta dosen dan lembaga, dalam hal ini jurusan, faklutas, dan universitas mampu bersinergi secara baik. Adanya kerjasama dan komitmen antara mahasiswa, dosen, dan lembaga diharapkan dapat mencegah dan menghilangkan budaya curang di dunia pendidikan khususnya di Jurusan Akuntansi sehingga lulusan yang dicetak memiliki kualitas akademik tinggi dan karakter yang baik.
\end{abstract}

Kata kunci: sinergi, mahasiswa, dosen, lembaga, pencegahan kecurangan akademik

\section{A. PENDAHULUAN}

Mahasiswa (colleger) merupakan generasi yang dapat mengubah suatu bangsa ke arah yang lebih baik. Hal ini dapat tercapai jika proses pembelajaran berjalan sesuai dengan kaidah, peraturan, maupun norma yang diberlakukan di dalam lingkungan akademiknya. Lembaga pendidikan tinggi memiliki tanggung jawab untuk mencetak lulusan yang terbaik dalam bidang akademik maupun non akademik, khususnya dalam hal pembetukan karakter yang baik. Kualitas lulusan tidak hanya ditentukan oleh tingginya Indeks Prestasi Kumulatif (IPK) yang didapatkan mahasiswa selama menempuh studi di suatu perguruan tinggi. Faktor lain seperti karakter turut berperan dalam menentukan kualitas lulusan. Banyak pihak yang mengharapkan setiap lulusan yang dihasilkan perguruan tinggi memiliki IPK tinggi dan karakter yang baik, sehingga ketika lulusan tersebut bekerja atau berwirausaha memiliki profesionalisma yang tinggi. Pendidikan yang dapat menghasilkan lulusan berkualitas dengan tingkat profesionalisma yang tinggi menjadi pendidikan ideal bagi generasi pengubah bangsa di masa depan.

Tuntutan akan perubahan kualitas generasi bangsa tentunya menjadi pekerjaan bagi berbagai pihak yang terlibat dalam bidang pendidikan. Kualitas pembelajaran dan disiplin akademik menjadi hal yang harus diperhatikan. Salah 
satu kunci kemajuan bangsa Indonesia ditentukan oleh kualitas sumber daya manusia yang berada dalam bangsa tersebut. Hal ini akan didapatkan ketika kualitas pendidikan di Indonesia dalam mencetak lulusan yang tidak hanya memiliki prestasi akademik yang tinggi, namun juga memiliki karakteristik individu yang baik berdasarkan atas norma dan budaya yang ada di Indonesia.

Banyaknya tindakan kecurangan akademik yang dilakukan di berbagai ranah akademik yang ada di Indonesia menunjukkan sedikit atau bahkan belum adanya pendidikan di Indonesia yang mampu mencetak sumber daya manusia yang berkualitas, khususnya dari sisi pembetukan karakter individu mahasiswa. Pendidikan tinggi juga tidak terhindar dari adanya tindakan kecurangan akademik. Tindakan kecurangan akademik juga terjadi pada mahasiswa di Jurusan Akuntansi. Berbagai tindakan kecurangan akademik dilakukan mahasiswa Jurusan Akuntansi, yang merupakan calon lulusan dari perguruan tinggi, dengan berbagai alasan dan tujuan. Beberapa tindakan kecurangan akademik yang dilakukan oleh mahasiswa antara lain mencontek saat ujian, menyalin (copy paste) jawaban teman, menyalin dari internet tanpa menyebutkan sumbernya, plagiarisma, titip tanda tangan kehadiran, mempersiapkan contekan untuk ujian, menyalin tugas teman, bertanya kepada teman saat ujian atau kuis, melirik atau melihat jawaban teman, memberitahu jawaban kepada teman saat ujian atau kuis, dan masih banyak hal lain yang dapat dimasukkan ke dalam kriteria kecurangan akademik. Banyaknya tindakan kecurangan akademik yang dilakukan oleh mahasiswa dapat berdampak buruk khususnya bagi tempat mereka berkarier. Lulusan dari Jurusan Akuntansi merupakan lulusan yang berada dalam posisi cukup menguntungkan. Hampir di semua Departemen/Kementerian di Indonesia atau perusahaan membutuhkan lulusan dari Jurusan Akuntansi khususnya untuk mengelola keuangan mereka. Jika lulusan yang bekerja atau berkarier di berbagai tempat ini merupakan lulusan yang sering bertindak curang, maka dapat menyebabkan munculnya berbagai kasus kejahatan, seperti pemalsuan laporan keuangan atau penyelewengan dana. Hal ini tentunya tidak diinginkan oleh berbagai pihak.

Kecurangan akademik yang dilakukan oleh mahasiswa sebenarnya ada yang disadari namun ada pula yang tidak disadari bahwa yang mereka lakukan sebenarnya merupakan sebuah tindakan kecurangan yang dapat dikenai sanksi. Adanya keinginan untuk memperoleh IPK tinggi, kebanggaan, atau hanya sebatas karena harga diri terkadang membuat mahasiswa melakukan tindakan kecurangan akademik. Berbagai bentuk kecurangan inilah yang akan mengikis karakter mahasiswa sebagai individu yang akan mengemban amanah bangsa untuk menjadi generasi pengubah bangsa menuju ke arah yang lebih baik. Terungkapnya kasus-kasus di Indonesia, seperti korupsi, penipuan, plagiarisma, penggelapan pajak, atau pun suap merupakan kasus yang pelakunya memiliki kualifikasi pendidikan tinggi. Hal ini membuktikan bahwa karakter lulusan perguruan tinggi yang tidak baik.

Mahasiswa harus mampu berbenah ke arah yang lebih baik, agar mereka dapat menjadi lulusan dengan prestasi akademik dan karakter yang baik. Salah satu upaya yang dapat dimulai dengan meningkatkan kesadaran akan berbagai kecurangan akademik dan berusaha menghindarinya. Mahasiswa dapat menghindari perbuatan curang, jika mereka sadar bahwa apa yang hendak mereka lakukan merupakan tindakan kecurangan akademik. Mahasiswa baik secara individu maupun bersama-sama harus memerangi berbagai kemungkinan 
munculnya tindakan kecurangan akademik. Peran dari mahasiswa sangat diperlukan untuk mencegah adanya tindakan kecurangan akademik, khususnya dalam proses pembelajaran.

Peran yang tidak kalah penting dari mahasiswa adalah peran dosen. Peran dari dosen sangat dibutuhkan untuk mencegah adanya tindakan kecurangan akademik. Selama ini, tidak banyak dosen yang memperhatikan berbagai tindakan kecurangan yang dilakukan oleh mahasiswa. Tugas dosen yang difokuskan pada pembelajaran sebenarnya tidak hanya menuntut dosen untuk mengajar di kelas namun juga mendidika mahasiswa agar menjadi insan yang lebih baik di berbagai aspek. Namun, tidak sedikit dosen yang menyatakan bahwa tugasnya adalah mengajar di kelas, memberi tugas dan ujian, dan memberi nilai. Hanya sedikit dosen yang peduli terhadap apa yang dilakukan oleh mahasiswa secara detail baik di dalam kelas maupun di luar kelas. Banyaknya mahasiswa yang berbuat curang dalam proses pembelajaran seolah lepas dari perhatian dosen yang bersangkutan, sehingga mahasiswa seringkali berusaha untuk mengulangi perbuatan curang tersebut. Jika dosen mengetahui ada mahasiswa yang melakukan kecurangan akademik, hanya sebatas diingatkan tanpa diberikan sanksi berat yang dapat membuat mahasiswa berpikir ulang untuk mengulangi perbuatan mereka. Pencegahan tindakan kecurangan akademik khusunya dalam pembelajaran akan berhasil dilaksanakan jika dosen ikut berperan serta didalamnya.

Selain mahasiswa dan dosen, peran yang diharapkan adalah peran dari lembaga, yaitu perguruan tinggi baik tingkat jurusan maupun fakultas sangat dibutuhkan. Berbagai peraturan sebenarnya telah dibuat dan ditetapkan oleh perguruan tinggi untuk mencegah adanya tindakan kecurangan akademik. Peraturan ini tercantum dalam peraturan akademik yang biasanya diberikan kepada mahasiswa ketika masuk ke perguruan tinggi yang bersangkutan. Namun, peraturan ini tidak sepenuhnya dilaksanakan dan ditaati oleh mahasiswa, bahkan cenderung diabaikan. Tindakan kecurangan akademik yang dilakukan oleh mahasiswa tidak mendapatkan sanksi yang sesuai atau bahkan terkadang tidak mendapatkan sanksi. Rendahnya atau tidak adanya sanksi yang berat, membuat mahasiswa tidak khawatir atau takut akan hukuman yang mungkin diterima jika mereka melakukan tindakan kecurangan akademik. Penerapan dan penegakan peraturan disertai dengan pengendalian dan sanksi yang sesuai bagi pelanggarnya merupakan upaya yang harus dilakukan untuk mencegah kecurangan akademik.

Peran dari ketiga elemen pendidikan tinggi, yaitu mahasiswa, dosen, dan lembaga sangat diperlukan untuk mencegah munculnya tindakan kecurangan akademik, khususnya yang dilakukan oleh mahasiswa. Ketiga elemen ini harus bahu-membahu untuk menghadapi berbagai bentuk kecurangan, baik yang sudah terjadi maupun yang mungkin terjadi. Keberhasilan pencegahan tindakan kecurangan akademik sangat bergantung pada kerjasama dan peran serta dari ketiga elemen pendidikan tinggi tersebut. Jika salah satu di antara ketiga elemen tersebut tidak mendukung, maka keberhasilan pencegahan tindakan kecurangan akademik akan sulit untuk diwujudkan.

\section{B. PEMBAHASAN}

\section{Kecurangan Akademik}

Kecurangan adalah perbuatan tidak jujur dan melanggar peraturan yang dilakukan untuk mencapai tujuan tertentu. Kecurangan dapat terjadi di berbagai 
lingkungan, termasuk lingkungan akademik. Kecurangan akademik (academic dishonesty) merupakan berbagai bentuk perilaku yang mendatangkan keuntungan bagi mahasiswa secara tidak jujur termasuk didalamnya mencontek, plagiarisme, mencuri, dan memalsukan sesuatu yang berhubungan dengan akademis (Hendricks, 2004), Pada dasarnya kecurangan akademik dilakukan oleh mahasiswa dengan sengaja ataupun tidak sengaja dengan berbagai tujuan dan alasan. Di sisi lain Lambert, Hogan dan Barton (2003) menyatakan bahwa kecurangan akademik sangat sulit untuk didefinisikan secara jelas. Kecurangan akademik merupakan salah satu tindakan yang bertentangan dengan etika. Kecurangan akademik dapat terjadi ketika mahasiswa melakukan berbagai cara yang tidak baik untuk mencapai tujuan dan keberhasilan. Kecurangan akademik dapat dilakukan mahasiswa khususnya dalam proses pembelajaran. Dalam pembelajaran akuntansi yang merupakan salah satu mata kuliah yang didalamnya terdapat teori dan praktik, serta membutuhkan banyak perhitungan yang dapat membuat mahasiswa merasa kesulitan, menimbulkan peluang terjadinya kecurangan akademik. Berbagai peraturan yang ada seolah diabaikan bahkan cenderung dilanggar. Perilaku mencontek, menulis rumus di kalkulator, menyalin ujian atau tugas, titip tanda tangan, atau bertanya saat ujian atau kuis merupakan contoh dari tindakan kecurangan akademik yang dilakukan oleh mahasiswa.

Kecurangan akademik terjadi di dalam pembelajaran disebabkan oleh faktorfaktor yang berasal baik dari dalam diri mahasiswa maupun dari luar. Menurut Hendricks (2004) terdapat beberapa faktor yang mempengaruhi kecurangan akademis, yaitu:

1. Faktor individual. Terdapat berbagai variabel yang mampu mengidentifikasikan karakteristik personal yang dapat digunakan untuk memprediksi perilaku curang. Variabel-variabel tersebut adalah:

a. Usia. Mahasiswa yang berusia lebih muda lebih banyak melakukan kecurangan akademis daripada mahasiswa yang lebih tua.

b. Jenis kelamin. Mahasiswa lebih banyak melakukan kecurangan akademis daripada mahasiswi. Penjelasan utama dari pernyataan ini dapat dijelaskan oleh teori sosialisasi peran gender yakni wanita dalam bersosialisasi lebih mematuhi peraturan daripada pria.

c. Prestasi akademis. Hubungan antara kecurangan akademis dan prestasi akademis tidak seperti hubungan kecurangan akademis dengan usia ataupun jenis kelamin, hubungan antara kecurangan akademis dengan prestasi akademis bersifat konsisten. Mahasiswa yang memiliki prestasi akademis rendah lebih banyak melakukan kecurangan akademis daripada mahasiswa yang memiliki prestasi yang lebih tinggi. Mahasiswa yang memiliki prestasi akademis yang rendah berusaha memperoleh prestasi akademis yang lebih tinggi dengan cara berperilaku curang dan lebih mau mengambil risiko daripada mahasiswa yang memiliki prestasi akademis yang tinggi.

d. Pendidikan orangtua. Mahasiswa dari keluarga yang memiliki latar belakang pendidikan yang tinggi akan lebih baik dalam mempersiapkan diri dalam mengerjakan tugas yang diberikan oleh fakultas. Selain itu, mahasiswa tersebut juga akan memiliki komitmen yang cenderung tinggi dalam pendidikan yang dijalaninya. Komitmen yang tinggi ini dapat menjadi faktor pencegah kecurangan akademis. 
e. Aktivitas ekstrakurikuler. Banyak mahasiswa yang memiliki tingkat kecurangan akademis yang tinggi dilaporkan terlibat di dalam aktivitas ekstrakurikuler. Mahasiswa yang tergabung di dalam kegiatan ekstrakurikuler memiliki komitmen yang lebih rendah berkaitan dengan pendidikan. Dua aktivitas yang telah diteliti secara ekstensif adalah mahasiswa yang tergabung di dalam perkumpulan mahasiswa dan kegiatan olahraga.

2. Faktor kepribadian mahasiswa. Beberapa hal yang berkaitan dengan kepribadian mahasiswa yang dapat memunculkan perilaku curang antara lain adalah:

a. Moralitas. Mahasiswa yang memiliki level kejujuran yang rendah akan lebih sering melakukan perilaku curang. Selain itu, mahasiswa yang memiliki tingkat religiusitas yang rendah cenderung lebih banyak melakukan kecurangan akademis.

b. Variabel yang berkaitan dengan pencapaian akademis. Variabel yang berkaitan dengan kecurangan akademis adalah motivasi, pola kepribadian dan pengharapan terhadap kesuksesan. Motivasi berprestasi memiliki hubungan yang positif dengan perilaku curang. Selain itu, pola kepribadian dan pengharapan terhadap kesuksesan memiliki hubungan negatif dengan perilaku curang.

c. Impulsivitas, afektivitas, dan variabel kepribadian yang lain. Terdapat hubungan antara perilaku curang dengan impulsivitas dan kekuatan ego. Selain itu mahasiswa yang memiliki level tinggi dari tes kecemasan lebih cenderung melakukan perilaku curang.

3. Faktor kontekstual

a. Keanggotaan perkumpulan mahasiswa. Mahasiswa yang tergabung dalam suatu perkumpulan mahasiswa akan lebih sering melakukan perilaku curang. Pada perkumpulan mahasiswa diajarkan norma, nilai dan kemampuan-kemampuan yang berhubungan dengan mudahnya perpindahan perilaku curang. Pada suatu perkumpulan, penyediaan catatan ujian yang lama, tugas-tugas, tugas laboratorium dan tugas akademis lain mudah untuk dicari dan didapatkan.

b. Perilaku teman sebaya. Perilaku teman sebaya memiliki pengaruh yang penting terhadap kecurangan akademis. Hubungan ini dapat dijelaskan dengan menggunakan teori pembelajaran sosial (Social Learning Theory) dari Bandura dan teori hubungan perbedaan (Differential Association Theory) dari Edwin Sutherland. Teori-teori tersebut mengemukakan bahwa perilaku manusia dipelajari dengan mencontoh perilaku orang lain dan individu yang memiliki hubungan dekat dengan individu lain yang memiliki perilaku menyimpang akan berpengaruh terhadap peningkatan perilaku individu yang menirunya.

c. Penolakan teman sebaya terhadap perilaku curang. Penolakan teman sebaya terhadap perilaku curang merupakan salah satu faktor penentu yang penting dan dapat berpengaruh terhadap perubahan perilaku curang pada mahasiswa.

4. Faktor situasional

a. Belajar terlalu banyak, kompetisi dan ukuran kelas. Mahasiswa yang belajar terlalu banyak dan menganggap dirinya berkompetisi dengan mahasiswa 
lain lebih cenderung melakukan kecurangan dibandingkan mahasiswa yang tidak belajar terlalu banyak. Ukuran kelas juga menentukan kecenderungan perilaku curang mahasiswa dimana mahasiswa akan lebih berperilaku curang jika berada di dalam ruangan kelas yang besar.

b. Lingkungan ujian. Mahasiswa lebih cenderung melakukan kecurangan di dalam ruangan ujian jika mahasiswa tersebut berpikir bahwa hanya ada sedikit resiko ketahuan ketika melakukan kecurangan.

Abdullah Alhadza (2001) menjelaskan bahwa ada empat faktor yang menjadi penyebab kecurangan akademik yaitu: faktor individual atau pribadi, faktor lingkungan atau pengaruh kelompok, faktor sistem evaluasi dan faktor guru, dosen, atau penilai. Lebih lanjut Matindas (2010) menambahkan bahwa kecurangan akademik muncul sebagai interaksi berbagai faktor, baik yang bersifat internal (ada di dalam diri pelaku) maupun yang bersifat eksternal (berasal dari lingkungan). Alfindra Primaldi (Matindas, 2010) menyebutkan bahwa banyak sekali faktor yang berkaitan dengan kecurangan akademik. Faktor yang bersifat internal antara lain meliputi academic self-efficacy, indeks prestasi akademik, etos kerja, self-esteem, kemampuan atau kompetensi motivasi akademik (need for approval belief), sikap (attitude), tingkat pendidikan teknik belajar (study skill), dan moralitas. Selain itu, faktor yang bersifat eksternal antara lain meliputi pengawasan oleh pengajar, penerapan peraturan, tanggapan pihak birokrat terhadap kecurangan, perilaku siswa lain serta asal negara pelaku kecurangan.

Berdasarkan beberapa pendapat tersebut, dapat ditarik benang merah bahwa faktor kecurangan akademik berasal dari dalam diri mahasiswa dan dari lingkungan luar. Beberapa faktor internal yang memicu munculnya kecurangan akademik adalah tingkat kesadaran, kemampuan diri, motivasi, kepribadian, moralitas, kepercayaan diri, harga diri, dan kadar keimanan, sedangkan faktor yang bersal dari lingkungan luar antara lain pengaruh teman, keadaan, faktor dosen, dan peraturan lembaga.

Banyaknya faktor yang dapat memunculkan tindakan kecurangan akademik mengakibatkan munculnya berbagai kejadian atau kasus kecurangan akademik yang ada dalam proses pembelajaran di perguruan tinggi. Berbagai macam tindakan kecurangan akademik yang muncul di berbagai perguruan tinggi berbeda-beda. Secara garis besar beberapa bentuk kecurangan akademik yang terjadi dalam pembelajaran akuntansi antara adalah sebagai berikut (adopsi dan modifikasi dari Hendricks, 2004):

1. Mahasiswa menyiapkan catatan kecil untuk ujian atau kuis.

2. Penggunaan catatan/contekan pada saat ujian atau kuis.

3. Menyalin jawaban orang lain ketika ujian.

4. Menggunakan metode-metode yang tidak jujur untuk mengetahui apa yang akan diujikan.

5. Menyalin jawaban ujian dari orang lain tanpa sepengetahuan orang tersebut.

6. Membantu orang lain untuk berlaku curang.

7. Menyalin tugas karya ilmiah orang lain dan mengakuinya sebagai pekerjaan sendiri (menjiplak).

8. Memalsukan daftar pustaka

9. Melakukan kerja sama dengan pengajar untuk menyelesaikan tugas individu

10. Menyalin beberapa kalimat (termasuk dari internet) tanpa memasukkan keterangannya ke dalam daftar pustaka (plagiat). 
11. Membeli karya ilmiah dari orang lain

12. Menggunakan berbagai alasan palsu untuk memperpanjang pengumpulan tugas.

13. Menyuap, memberi hadiah, atau mengancam orang lain untuk kepentingan diri sendiri.

14. Titip tanda tangan kehadiran.

15. Meminta orang lain untuk menggantikan dirinya atau menggantikan orang lain untuk mengikuti ujian.

16. Bekerjasama dengan orang lain saat ujian atau kuis secara lisan, isyarat, atau menggunakan media komunikasi seperti handphone.

17. Memberikan perhitungan jawaban atau bahkan jawaban kepada orang lain menggunakan media kertas.

Colby (2006) menyatakan bahwa di Arizuna State University kategori kecurangan akademik dibagi menjadi lima kategori, yaitu:

1. Plagiat

a. Menggunakan kata-kata atau ide orang lain tanpa menyebut atau mencantumkan nama orang tersebut.

b. Tidak menggunakan tanda kutipan dan menyebut sumber ketika menggunakan kata-kata atau ide pada saat mengerjakan laporan, makalah dari bahan internet, majalah, koran, dll.

2. Pemalsuan data, misalnya membuat data ilmiah yang merupakan data fiktif.

3. Penggandaan tugas, yakni mengajukan dua karya tulis yang sama pada dua kelas yang berbeda tanpa izin dosen.

4. Menyontek pada saat ujian

a. Menyalin lembar jawaban orang lain.

b. Menggandakan lembar soal kemudian memberikannya kepada orang lain.

c. Menggunakan teknologi untuk mencuri soal ujian kemudian diberikan kepada orang lain atau seseorang meminta orang lain mencuri soal ujian kemudian diberikan kepada orang tersebut.

5. Kerjasama yang salah

a. Bekerja dengan orang lain untuk menyelesaikan tugas individual

b. Tidak melakukan tugasnya ketika bekerja dengan sebuah tim.

Pavela (Lambert, Hogan dan Barton, 2003) menyebutkan hal yang senada dengan Colby bahwa umumnya ada empat hal yang termasuk kecurangan akademik, yaitu: (1) menyontek dengan menggunakan materi yang tidak sah dalam ujian, (2) menggunakan informasi, referensi atau data-data palsu, (3) plagiat, (4) membantu mahasiswa lain untuk menyontek seperti membiarkan mahasiswa lain menyalin tugasnya, memberikan kumpulan soal-soal yang sudah diujikan, mengingat soal ujian kemudian membocorkannya.

Anitsal, Anitsal, dan Elmore (2009: 19) menambahkan bahwa ada dua kategori kecurangan akademik yaitu kecurangan akademik pasif dan kecurangan akademik aktif. Perilaku kecurangan akademik pasif meliputi melihat orang lain menyontek tapi tidak melaporkannya, memberikan informasi tentang soal ujian kepada orang yang belum ujian di mata pelajaran yang sama. Perilaku kecurangan akademik aktif meliputi perilaku meminta orang lain untuk mengambil soal ujian, menyalin jawaban dari orang lain, dan menggunakan telepon seluler untuk meminta atau mengirimkan jawaban. 


\section{Pensinergian Mahasiswa, Dosen, dan Lembaga dalam Pencegahan Kecurangan Akademik}

Mata kuliah yang ada di Jurusan Akuntansi sebagian besar adalah mata kuliah yang didalamnya mengandung unsur hitung-hitungan. Tidak sedikit mahasiswa yang sering mengalami kesulitan dalam menyelesaikan tugas, kuis, atau ujian yang diselenggarakan dalam kegiatan pembelajaran. Adanya kesulitan yang dihadapi dan beberapa faktor lain seperti karakter mahasiswa dapat memunculkan tindakan kecurangan akademik yang dilakukan mahasiswa, baik sadar maupun tidak sadar. Banyaknya kecurangan akademik yang dilakukan mahasiswa dapat berdampak negatif bagi berbagai pihak. Mulyawati, dkk. (2010: 44) mengemukakan bahwa akibat dari kecurangan akademik akan memunculkan dalam diri mahasiswa perilaku atau watak yang tidak percaya diri, tidak disiplin, tidak bertanggung jawab, tidak kreatif, tidak berprestasi, tidak mau membaca buku pelajaran tapi siswa lebih rajin membuat catatan-catatan kecil untuk bahan menyontek.

Budaya curang yang terbentuk dalam diri mahasiswa akan mengikis budayabudaya baik yang ada seperti budaya disiplin dalam lembaga pendidikan sehingga dampaknya tidak hanya akan merusak integritas dari pendidikan itu sendiri, namun bisa menyebabkan perilaku yang lebih serius seperti tindakan kriminal (Mulyawati, dkk, 2010: 46). Anitsal, Anitsal, dan Elmore (2009: 17) mempertegas pernyataan Mulyawati bahwa memang ada korelasi positif antara kecurangan akademik dengan perilaku tidak etis.

Buruknya dampak yang ditimbulkan dari tindakan kecurangan akademik memicu berbagai pihak untuk segera mengatasinya. Harapan untuk menjadi bangsa yang lebih baik akan terwujud jika sejak dini berbagai tindakan kecurangan yang ada, khususnya di dunia pendidikan harus segera dicegah. Mahasiswa sebagai kunci utama pencegahan kecurangan akademik memegang peranan penting agar kecurangan akademik tindak muncul dalam proses pembelajaran di perguruan tinggi. Banyaknya faktor yang berasal dari mahasiswa yang mempengaruhi munculnya tindakan kecurangan akademik harus mampu diatasi oleh mahasiswa baik secara individu maupun secara berkelompok.

Selain mahasiswa, dosen sebagai pendidik mahasiswa di perguruan tinggi juga memiliki peranan penting dalam mencetak lulusan yang berkualitas dan berkarakter baik. Adanya kemungkinan munculnya berbagai tindakan kecurangan akademik harus diperhatikan oleh dosen agar sebisa mungkin mahasiswa tidak melakukannya. Piha lain yang tak kalah penting perannya adalah lembaga, baik jurusan, faklutas, maupun universitas. Lembaga memiliki peran dan tanggung jawab untuk mencegah munculnya kecurangan akademik terutama dalam hal penetapan peraturan dan sanksi yang tepat.

Pensinergian ketiga pihak, yaitu mahasiswa, dosen, dan lembaga, di dalam upaya mencegah kecurangan akademik perlu diwujudkan. Jika salah satu pihak tidak dapat bersinergi atau tidak dapat mendukung, maka upaya pencegahan tindakan kecurangan akademik sulit untuk dilaksanakan. Sebagai contoh, mahasiswa dan lembaga sudah berkomitmen untuk mencegah kecurangan akademik, namun dosen memberikan kesempatan dan tidak pernah memberikan perhatian lebih, tentunya akan membuat mahasiswa memanfaatkan peluang yang diberikan tersebut. Begitu pula dengan pihak yang lain. 
Peran satu pihak dengan pihak yang lain tidak dapat dipisahkan agar upaya pencegahan dapat berjalan sesuai dengan yang diharapkan. Berikut merupakan peran-peran yang dapat diambil oleh masing-masing pihak untuk mencegah atau mengatasi adanya berbagai bentuk tindakan kecurangan akademik khususnya kecurangan dalam kuis/ujian, kecurangan dalam tugas, dan kecurangan akademik lain yang dilakukan berkaitan dengan proses pembelajaran baik di dalam kelas maupun luar kelas yang dapat dilakukan oleh mahasiswa akuntansi.

1. Kecurangan dalam kuis/ujian. Kecurangan yang dapat dilakukan mahasiswa saat mengikuti kuis atau ujian antara lain adalah: (1) Mahasiswa menyiapkan catatan kecil untuk ujian/kuis; (2) Mahasiswa menggunakan catatan yang sudah disiapkan ketika mengerjakan soal kuis/ujian; (3) Mahasiswa bertanya kepada mahasiswa lain melalui lisan, isyarat, atau pemanfaatan media komunikasi; (4) Mahasiswa melihat baik sepengetahuan atau tanpa sepengetahuan mahasiswa lain lembar jawab kuis/ujian; (5) Mahasiswa memberikan jawaban kepada mahasiswa lain melalui berbagai media, seperti kertas, kartu ujian, atau kalkulator; (6) Mahasiswa mencari bocoran soal atau jawaban kuis/ujian; (7) Mahasiswa mencuri soal kuis/ujian dan diberikan kepada mahasiswa yang belum mengikuti kuis/ujian; (8) Mahasiswa bekerjasama dengan pengawas kuis/ujian; (9) Mahasiswa menyuap atau memberi hadiah untuk keberhasilan kuis/ujiannya, dan (10) Mahasiswa mencari jawaban kuis/ujian menggunakan internet.

Pencegahan kecurangan dalam kuis/ujian harus dilakukan oleh mahasiswa, dosen, dan lembaga. Berikut merupakan peran, kegiatan, atau tindakan yang dapat diambil oleh pihak terkait untuk mencegah atau mengatasi kecurangan dalam kuis/ujian.

a. Mahasiswa

Beberapa hal yang dapat dilakukan mahasiswa akuntansi untuk mencegah adanya kecurangan akademik dalam kuis/ujian antara lain:

1. Mahasiswa mempersiapkan kuis/ujian dengan belajar lebih giat.

2. Mahasiswa membuat target realistis sesuai dengan kemampuannya.

3. Mahasiswa meningkatkan kesadaran akan kedisiplinan dan kode etik.

4. Mahasiswa membangun kepercayaan diri.

5. Mahasiswa membentuk kelompok belajar untuk mengatasi kesulitan yang dihadapi.

6. Mahasiswa selalu bertanya kepada dosen atau mahasiswa lain jika menemui kesulitan dalam pembelajaran akuntansi.

7. Mahasiswa melaporkan kecurangan yang dilakukan oleh mahasiswa lain.

b. Dosen

Beberapa hal yang dapat dilakukan dosen untuk mencegah adanya kecurangan akademik dalam kuis/ujian antara lain:

1. Dosen menggunakan model pembelajaran yang membuat semua mahasiswa memahami materi yang disampaikan.

2. Dosen memotivasi mahasiswa untuk selalu bertindak disiplin dan beretika.

3. Dosen membantu mahasiswa yang mengalami kesulitan di dalam proses pembelajaran.

4. Dosen memberikan aturan dan sanksi yang tegas terhadap berbagai bentuk kecurangan. 
5. Dosen turut menjadi pengawas saat kuis/ujian dilaksanakan.

6. Dosen menjadi teladan dalam hal kedisiplinan.

c. Lembaga

Beberapa hal yang dapat dilakukan lembaga untuk mencegah adanya kecurangan akademik dalam kuis/ujian antara lain:

1. Lembaga menerapkan aturan dan sanksi akademik dengan tegas.

2. Lembaga mensosialisasi secara rutin aturan dan sanksi akademik kepada dosen dan mahasiswa.

3. Lembaga memberikan fasilitas yang memadai untuk mendukung pembelajaran yang berkualitas.

4. Lembaga langsung memberi sanksi yang sesuai ketika terjadi pelanggaran baik mahasiswa maupun dosen.

5. Lembaga melakukan pengawasan ketat ketika kuis/ujian berlangsung.

2. Kecurangan dalam pengerjaan tugas. Kecurangan akademik yang terjadi dalam pengerjaan tugas merupakan berbagai bentuk kecurangan yang dilakukan oleh mahasiswa baik saat mengerjakan tugas kuliah maupun tugas akhir. Kecurangan yang dapat dilakukan mahasiswa saat mengerjakan tugas antara lain adalah: (1) Mahasiswa menyalin tugas mahasiswa lain; (2) Mahasiswa menyalin tugas dari internet tanpa menyebutkan sumbernya; (3) Mahasiswa mengumpulkan tugas mahasiswa lain yang telah diganti nama (penggandaan tugas secara ilegal); (4) Mahasiswa mengutip kalimat tanpa menyebutkan sumbernya (plagiat); (5) Mahasiswa memalsukan daftar pustaka; (6) Mahasiswa memanipulasi data penelitian; (7) Mahasiswa membeli tugas akhir (skripsi) kepada pihak lain; (8) Mahasiswa menyuap atau memberi hadiah untuk mengerjakan tugasnya; (9) Mahasiswa memalsu tanda tangan dosen pembimbing; (10) Mahasiswa tidak berpartisipasi dalam pengerjaan tugas kelompok; (11) Mahasiswa bekerjasama untuk mengerjakan tugas individual; dan (12) Mahasiswa meminta penundaan waktu pengumpulan tugas.

Kecurangan dalam pengerjaan tugas yang dilakukan oleh mahasiswa dapat diatasi atau dicegah jika mahasiswa, dosen, dan lembaga mampu bekerjasama untuk menangani kecurangan tersebut. Berikut merupakan peran, kegiatan, atau tindakan yang dapat diambil oleh pihak terkait untuk mencegah atau mengatasi kecurangan dalam pengerjaan tugas.

a. Mahasiswa

Beberapa hal yang dapat dilakukan mahasiswa akuntansi untuk mencegah adanya kecurangan akademik dalam pengerjaan tugas antara lain:

1. Mahasiswa meningkatkan kesadaran akan pentingnya kedisiplinan dan kode etik.

2. Mahasiswa berani menolak untuk berbuat curang.

3. Mahasiswa meningkatkan kebanggaan untuk mengerjakan tugas secara mandiri tanpa berbuat curang.

4. Mahasiswa melaporkan perbuatan curang yang dilakukan mahasiswa lain.

5. Mahasiswa mengerjakan tugas dengan cara diskusi kelompok.

6. Mahasiswa meningkatkan keyakinan diri bahwa ia mampu mengerjakan tugas.

7. Mahasiswa tidak malu untuk bertanya kepada dosen jika menemukan kesulitan. 
8. Mahasiswa membiasakan diri untuk mencantumkan referensi dalam setiap tugasnya.

9. Mahasiswa harus mampu mengatur waktu untuk mengerjakan tugas.

b. Dosen

Beberapa hal yang dapat dilakukan dosen untuk mencegah adanya kecurangan akademik dalam pengerjaan tugas antara lain:

1. Dosen tidak membebani mahasiswa dengan banyaknya tugas yang tidak relevan.

2. Dosen memahamkan mahasiswa cara mengutip dengan benar.

3. Dosen memotivasi mahasiswa untuk selalu bertindak disiplin dan beretika dalam mengerjakan tugas.

4. Dosen mengarahkan dan memberikan panduan kepada mahasiswa dalam pengerjaan tugas secara jelas.

5. Dosen memberikan aturan dan sanksi yang tegas dan mendidik terhadap berbagai bentuk kecurangan dalam pengerjaan tugas.

6. Dosen mengawasi dan mengevaluasi serta mendeteksi kemungkinan adanya kecurangan dalam pengerjaan tugas.

7. Dosen menyediakan jadwal bimbingan secara jelas sehingga mudah ditemui oleh mahasiswa.

c. Lembaga

Beberapa hal yang dapat dilakukan lembaga untuk mencegah adanya kecurangan akademik dalam pengerjaan tugas antara lain:

1. Lembaga menerapkan aturan dan sanksi akademik dengan tegas.

2. Lembaga langsung memberi sanksi yang sesuai ketika terjadi pelanggaran baik mahasiswa maupun dosen.

3. Lembaga menyelenggarakan pendidikan moral atau karakter bagi dosen dan mahasiswa.

4. Lembaga menyelenggarakan pelatihan yang mendorong mahasiswa dan dosen untuk menghasilkan karya melalui gagasan orisinil.

3. Kecurangan akademik lain. Kecurangan akademik lain adalah kecurangan selain kecurangan saat ujian dan pengerjaan tugas. Beberapa bentuk kecurangan yang dilakukan oleh mahasiswa antara lain adalah: (1) Mahasiswa titip tanda tangan kehadiran; (2) Mahasiswa memberikan kesaksian palsu terhadap kecurangan yang terjadi; (3) Mahasiswa menandatangani daftar hadir tidak sesuai dengan jumlah kehadiran; dan (4) Mahasiswa memberikan hadiah kepada dosen agar mendapatkan nilai bagus.

Kecurangan yang dilakukan mahasiswa selain ketika ujian dan mengerjakan tugas biasanya dilakukan secara tidak sadar. Kecurangan ini perlu mendapatkan perhatian lebih dari mahasiswa, dosen, dan lembaga. Ketiga pihak tersebut mampu bekerjasama untuk menangani kecurangan tersebut. Berikut merupakan peran, kegiatan, atau tindakan yang dapat diambil oleh pihak terkait untuk mencegah atau mengatasi kecurangan yang dilakukan oleh mahasiswa.

a. Mahasiswa

1. Mahasiswa meningkatkan kesadaran akan berbagai bentuk kecurangan yang ada dan berusaha untuk menghindarinya.

2. Mahasiswa harus berani melaporkan perbuatan curang yang dilakukan oleh mahasiswa lain. 
3. Mahasiswa harus berani menolak untuk penawaran perbuatan curang.

4. Mahasiswa harus menghilangkan niatan tidak baik hanya untuk mendapatkan nilai yang baik.

b. Dosen

1. Dosen memberikan teladan yang baik bagi mahasiswa dan menunjukkan disiplin dan perilaku etis.

2. Dosen selalu memastikan kehadiran mahasiswa dalam setiap pertemuan kuliah.

3. Dosen tidak meminta mahasiswa untuk melakukan sesuatu yang dapat melanggar peraturan (misal: tanda tangan kehadiran melebihi pertemuan yang sebenarnya).

4. Dosen menindak tegas bagi mahasiswa yang berbuat curang dan memberikan sanski yang sesuai disertai dengan bimbingan agar mahasiswa tidak mengulangi perbuatannya.

c. Lembaga

1. Lembaga selalu mengawasi dosen dan mahasiswa dalam kegiatan pembelajaran khususnya di kelas.

2. Lembaga menindak tegas terhadap perbuatan curang baik yang dilakukan mahasiswa atau dosen.

3. Lembaga memiliki media khusus yang disediakan sebagai sarana untuk menerima laporan-laporan mengenai kecurangan yang terjadi.

Upaya penanggulangan atau pencegahan berbagai bentuk kecurangan akademik akan berhasil jika terdapat sinergi antara mahasiswa, dosen, dan lembaga. Peran dari ketiga pihak tersebut sangat diperlukan untuk mencegah adanya kemungkinan munculnya kasus kecurangan dalam proses pembelajaran. Matindas (2010) mengemukakan beberapa hal yang dapat dilakukan untuk mencegah adanya kecurangan akademik, khususnya pihak dosen dan lembaga mengambil peran penting untuk pencegahan kecurangan tersebut. Dosen dan lembaga harus mampu melakukan pengawasan ketat sebagi upaya pencegahan dan memberikan sanksi yang sesuai bagi mahasiswa yang melanggar peraturan atau berbuat curang sehingga mahasiswa tersebut tidak akan mengulangi perbuatannya.

Abdullah Alhadza (2001) menjelaskan bahwa agar mahasiswa tidak melakukan kecurangan akademik pada saat ujian, mahasiswa harus mampu memotivasi diri dan membangkitkan rasa percaya diri. Dosen juga dituntut untuk selalu objektif dalam pemberian nilai, bersikap rasional, serta dapat menunjukkan keteladanan. Lembaga juga harus mampu membuat sistem evaluasi yang tepat dan menguntungkan bagi semua pihak. Jika tidak ada piahk yang dirugikan, tindakan kecurangan tidak akan terjadi. Colby (2006) menambahkan bahwa untuk mencegah atau menghindari kecurangan akademik, mahasiswa harus berani bertanya jika ada kesulitan, menjaga kejujuran, dan kesehatan. Mulyawati, dkk. (2010) juga memaparkan upaya-upaya penanggulangan kecurangan akademik, khususnya budaya menyontek dibutuhkan adanya sanksi yang berat dan peran serta dari pemerintah dan mahasiswa yang bersangkutan.

Pada dasarnya pencegahan kecurangan akademik dapat berhasil dilakukan jika mahasiswa, dosen, dan lembaga mampu bekerjasama dengan baik dan memiliki komitmen bersama untuk mencegah timbulnya kecurangan akademik. Hal ini dapat dilakukan jika semua pihak dapat terbuka antara pihak yang satu 
dengan pihak yang lain. Berbagai masukkan dari mahasiswa dan dosen diperlukan oleh lembaga untuk membuat dan menetapkan aturan yang tepat. Di sisi lain, lembaga harus mampu merangkul pihak mahasiswa dan dosen untuk bersamasama menjunjung tinggi karakter dan budaya yang baik di lingkungan akademik. Dosen sebagai salah satu pemegang peran penting, harus mampu membimbing, mengarahkan, dan memotivasi mahasiswa ke arah yang lebih baik. Selain itu, dosen juga dituntut agar dapat menjadi teladan bagi mahasiswa.

\section{PENUTUP}

Berdasarkan pembahasan yang telah dikemukakan di atas dapat dilihat bahwa pencegahan tindakan kecurangan akademik yang terjadi dapat berhasil jika terdapat sinergi di antara mahasiswa, dosen, dan lembaga. Mahasiswa sebagai kunci utama harus berani mengambil langkah dan peran untuk mencegah berbagi bentuk kecurangan akademik. Mahasiswa dituntut mampu meningkatkan kesadaran akan pentingnya berbuat jujur dalam proses pembelajaran. Mahasiswa juga harus berani menolak untuk diajak berbuat curang, serta berani melaporkan kepada dosen atau lembaga jika menemukan kecurangan yang terjadi. Sikap terbuka dari dosen dan lembaga dalam menerima laporan, keluhan, atau pengaduan dari mahasiswa dapat membantu mahasiswa menyelesaikan masalah yang dihadapi dengan segera dan hal ini dapat menghindarkan niatan mereka untuk berperilaku curang.

Di sisi lain, dosen sebagai pendidik harus mampu menjadi teladan bagi mahasiswa. Dosen harus dapat berperilaku profesional, objektif, dan terbuka kepada mahasiswa dan lembaga agar proses pembelajaran dapat berjalan dengan lancar. Dosen juga harus memiliki komitmen yang tinggi untuk membimbing mahasiswa agar menjadi insan yang lebih baik dan terhindar dari tindakan kecurangan. Selain itu, dibutuhkan pula peran lembaga untuk mengawasi dan mengendalikan proses pembelajaran agar terhindar dari segala bentuk kecurangan akademik yang ada. Kerjasama yang terjalin antara ketiga pihak ini diharapkan dapat menanggulangi atau mencegah terjadinya kecurangan akademik yang dapat terjadi dan merugikan berbagai pihak.

\section{DAFTAR PUSTAKA}

Alhadza, A. (2001). Masalah Menyontek (Cheating) di Dunia Pendidikan. (http://www.depdiknas.go.id, diakes pada 13 Februari 2009).

Anitsal, I., Anitsal, M.M., \& Elmore, R. (2009). Academic dishonesty and intention to cheat: A model on active versus passive academic dishonesty as perceived by business student. Academic of Educational Leadership Journal, 13 (2): 17-26.

Colby, B. (2006). Cheating; What is it. (http://clas.asu.edu/files/AI\%20Flier.pdf, diakses pada 27 Juni 2010).

Hendriks, B. (2004). Academic Dishonesty: A Study In The Magnitude Of And Justifications For Academic Dishonesty Among College Undergraduate And Graduate Students. New Jersey: Rowan University. 
Lambert, E.G., Hogan, N.L., \& Barton, S.M. (2003). Collegiate academic dishonesty revisited: what have they done, how often have they done it, who does it, and why did they do it. Electronic Journal of Sosiology. (http://www.sociology.org/content/vol7.4/ lambert_etal.html, diakses pada 21 April 2013).

Matindas, R. (2010). Mencegah kecurangan akademik. (http://budimatindas.blogspot.com/ 2010/08/mencegah-kecuranganakademik.html, diakses pada 12 September 2013).

Mulyawati, H., Masturoh, I., Anwaruddin, I., Mulyati, L. Agustendi, S., \& Tartila, T.S.S. (2010). Pembelajaran Studi Sosial. Bandung: Alfabeta. 